\title{
Como fazer coisas-em-si com palavras
}

\section{Julio Cabrera/UnB}

\section{Resumo}

Duas questões fundamentais da filosofia kantiana (o caráter 'prático' da liberdade e o primado da prática sobre a teoria) podem colocar-se em termos da teoria da linguagem (a teoria dos atos performativos) de J.L. Austin. Dada a total ausência da questão da linguagem na filosofia de Kant, o trabalho estuda o alcance e a legitimidade desta 'transcriçào' lingüística das duas teses kantianas.
Abstract

Two fundamental issues of the Kantian philosophy (the 'practical' character of freedom and the primacy of praxis with respect to theory) can be put in terms of J.L. Austin's theory of language ( $a$ theory of performative acts). Given the total absence of the problem of language in Kant's philosophy, this article studies the scope and legitimacy of this linguistic 'transcript' of the two Kantian theses.

\section{Introdução}

Duas questōes fundamentais da filosofia kantiana (ligadas com as vinculaçôes entre os usos 'teórico' e 'prático' da razão) podem ser reexpostas mediante a teoria da linguagem de Austin (mais especificamente a teoria dos proferimentos performativos), através de uma linha de pensamento estruturalmente semelhante.

Uma importante questão preliminar será aqui a seguinte: qual será a força pretendida para esta mise-en-langage de alguns aspectos da teoria kantiana? O que se pretenderá sustentar através dela?

Três graus alternativos de 'compromisso' com essa versào lingüística de Kant - cada um deles mais forte do que o anterior - poderiam ser concebidos: (a) apresentar a leitura austiniana da teoria de Kant apenas como uma transcriçâo lingüística, esclarecedora porém dispensável; (b) apresentá-la como uma tese lingüística nào meramente transcritiva, que pudesse ser introduzida na teoria kantiana sem perturbaçòes teóricas; (c) apresentá-la, com a pretensào de substituir completamente a teoria original, como sendo desde sempre, na verdade, única e exclusivamente uma tese acerca da linguagem, o que tornaria ilegítima, além de supérflua e obsoleta, a apresentação nāo lingüística kantiana.

O posicionamento perante estas possibilidades é capital, devido ao fato comprovado da total 
ausência da questão da linguagem dentro da obra kantiana em geral. Se esta ausência estiver profundamente motivada pela própria construçào da filosofia kantiana, a versào lingüística de alguns dos seus aspectos seria inadequada e, talvez, francamente ilegítima e rejeitada por aquela mesma construção, na medida em que o compromisso com a versāo lingüística se movimentasse nos níveis (b) ou (c), ou seja, na medida em que fosse defendida como algo mais do que uma mera 'transcrição' inofensiva.

Marcelo Dascal, num texto chamado "Kant, linguagem e conhecimento empírico", nos lembra do "flagrante silêncio de Kant a respeito da linguagem", perguntando-se até que ponto seria possivel introduzir a questão linguagem dentro do seu pensamento. A sua conclusào consiste em afirmar que esse silêncio kantiano não é eventual nào se trataria, como Humboldt pensava, de simplesmente 'acrescentar' ao sistema de Kant uma teoria da linguagem -, senão que a própria estrutura do sistema kantiano rejeitaria qualquer rol de tipo fundamental por parte da linguagem, que a linguagem não poderia nunca fazer parte do aparato transcendental. A tentativa de fornecer algo assim como uma versão lingüistica de algumas teses kantianas deverá também nos dizer, pois, alguma coisa acerca das relações entre Filosofia Analítica e Filosofia Transcendental e, especificamente, algo sobre as tentativas da primeira de elucidar, através da aparelhagem linguiística, instâncias ou aparatos conceituais ligados com outras tradições filosóficas.

A minha estratégia será apresentar aqui o experimento austiniano e, numa reflexão posterior, determinar qual das três mencionadas seria a relaçào mais adequada que tal experimento deveria guardar com a teoria kantiana.

\section{O performativo como gramática da liberdade}

Já na primeira Crítica, Kant tenta explicar a maneira como se configura a passagem da esfera teórica para a prática: a liberdade era, na esfera teórica, "...uma idéia transcendental pura que, em primeiro lugar, não contém nada emprestado da experiência e cujo objeto, em segundo lugar, também não pode ser dado determinadamente em nenhuma experiência..." (Kant, $C R P, 561)$. Porém, na passagem para a esfera prática, a liberdade se manifesta já $a b$ initio como "um fato da razão pura prática", embora em nada consiga ampliar o conhecimento da natureza. 
...pode e deve admitir-se a sua possibilidade nesta relação prática sem, contudo, a conhecer e discernir de um modo teorético. Para esta última exigência, basta que, do ponto de vista prático, ela não encerre nenhuma impossibilidade (contradição) interna. Eis, pois, em comparação com a razão especulativa, um princípio simplesmente subjetivo de assentimento, o qual, sendo no entanto objectivamente válido para uma razâo igualmente pura, mas prática, confere às idéias de Deus e de imortalidade, mediante o conceito de liberdade, realidade objetiva e autoridade, mais ainda, a necessidade subjetiva...de as aceitar, sem que deste modo a razão seja alargada no conhecimento teorético... (Kant, CRPr, A7/8).

Nesta passagem, muda a relação da razão pura com a experiência:

...aqui intervém um conceito de causalidade justificado pela Crítica da razào pura, embora não suscetível de qualquer representação empírica, a saber, o de liberdade... A crítica da razão prática em geral tem, pois, a obrigação de impedir a razão empiricamente condicionada de pretender fornecer exclusivamente o princípio de determinação da vontade... Na subdivisào... da Analítica a ordem será por sua vez o inverso da que foi seguida na Crítica da razão pura especulativa. Com efeito, na presente iremos aos conceitos começando pelos princípios, e dos conceitos primeiramente iremos, se possível, aos sentidos... (Ibid., A 31/2).
A estas teses positivas, Kant apresenta, já na primeira Critica, uma tese crítico-negativa (ou 'dialética'), ao denunciar a metafísica tradicional pré-crítica pelo fato dela ter pretendido apresentar ideiais práticos ligados com o agir livre como se fossem objetos teóricos construídos categorialmente com o intuito de ampliar o conhecimento. Ao tentar-se o tratamento de ideais - como liberdade, alma, Deus como conceitos do entendimento, ao faltar a condiçâo esquemático-sensivel, gera-se apenas um noumenon, um objeto de pensamento nào contraditório porém sem qualquer aplicação na experiência.

\begin{abstract}
Por isso as categorias de certa maneira estendem-se mais além da intuiçào sensivel, porque pensam objetos em geral, sem considerar ainda o modo particular (da sensibilidade) em que estes possam ser dados. Todavia, elas não determinam com isso uma esfera maior de objetos... (Kant, CRP, 309/10).
\end{abstract}

Temos nestes textos, pois, duas idéias fundamentais: (a) uma afirmativa - a liberdade é real na medida em que é possível inverter a relação cognitivo-teorética com a natureza, fazendo com que possam agora instaurar-se objetos segundo uma causalidade livre, diferente e mesmo contrária à coaçào da causalidade natural; (b) uma negativa - a 
filosofia tradicional (pré-crítica) recorrentemente confundiu ambas direçòes da razào, mesclando ilegitimamente objetos teoreticamente constituídos com objetos constituídos pela liberdade.

Esta primeira questão - que denominarei passagem da esfera teórica para a prática (ou: T-P) - é a primeira de duas questões kantianas fundamentais que pretendo transcrever em termos austinianos. Nas primeiras páginas do livro conhecido como How to do things with words (série de conferências compiladas por J.O. Urmson em 1962, dois anos após a morte do autor), Austin apresenta uma questào fundamental que parece mostrar, no tecido da sua exposição, uma estrutura semelhante à kantiana, no contexto da questão T-P. "Por mais tempo que o necessário [declara Austin] os filósofos acreditaram que o papel de uma declaraçào era tão-somente o de 'descrever' um estado de coisas, ou declarar um fato, o que deveria fazer de modo verdadeiro ou falso." (Cfr. How to do things with words, Oxford, 1980, ou a versão portuguesa de Danilo Marcondes: Quando dizer é fazer. Palavras e Açōes. Porto Alegre: Ed. Artes Médicas, 1990, p. 21).

Recentemente, porém, muitas das sentenças que antigamente teriam sido aceitas indiscutivelmente como 'declaraçôes', tanto por filósofos como por gramáticos, foram examinadas com um novo rigor. (...) Passou-se geralmente a considerar que muitos proferimentos que parecem declarações não têm, ou têm apenas em parte, o propósito de registrar ou transmitir informação direta acerca dos fatos. Por exemplo, as 'proposiçóes éticas' talvez tenham propósito, no todo ou em parte, de manifestar emoção ou prescrever comportamento, ou influenciá-lo de modo especial. (Ibid, 22).

A certeza de estar colocando aqui uma questão kantiana está presente no texto de Austin, no qual Kant é duas vezes lembrado: "Em um primeiro momento e de forma mais óbvia, mostrou-se que muitas 'declaraçôes', como Kant sustentou de maneira sistematica, eram estritamente sem-sentido, apesar de sua forma claramente gramatical..." (Ibid. 22). E ao referir-se às 'proposições éticas', Austin declara que "Aqui também Kant deve ser considerado como um dos pioneiros" (Ibid). Mas Austin não se aprofunda nesta relação com Kant, nem a tematiza novamente.

Numa primeira tentativa de conceituação da problemática que lhe interessa, Austin apresenta a famosa distinção entre proferimentos 'constativos' e proferimentos 'performativos'. Os primeiros teriam a capacidade de descrever aquilo que é o caso - fatos, ações, etc. - 
enquanto que os segundos - quase nào estudados por filósofos e gramáticos, segundo Austin - teriam a peculiaridade de fazer com que algo viesse a ser o caso, de realizar alguma coisa no próprio ato do proferimento e através dele. Austin proporciona alguns exemplos de performativos fortemente institucionalizados, como casamentos, batizados de navios e testamentos ("Aceito X como legítima esposa", "Batizo este navio como Rainha Elisabeth", 'Lego esta casa para Y').

Todos teräo, como é natural, verbos usuais na primeira pessoa do singular do presente do indicativo da voz ativa. Podem-se encontrar proferimentos que satisfaçam estas condiçöes e A. que nada 'descrevam' nem 'relatem', nem constatem, e nem sejam 'verdadeiros ou falsos', B. cujo proferimento da sentença é, no todo ou em parte, a realização de una ação, que não seria normalmente descrita consistindo em dizer algo. (Ibid, 24).

Austin apresenta os 'performativos' como nào sendo suscetíveis de serem verdadeiros ou falsos, mas apenas como sendo bem ou malsucedidos, ou como 'felizes' ou 'infelizes' (Austin dedicará as conferências II, III e IV à tentativa de formular critérios para un performativo bem-sucedido). Esta primeira articulação (constativo/performativo) passará por muitas vicissitudes até chegar, na conferência VIII, à uma nova tentativa de conceituaçào da distinção, mas me interessa determe na distinção por ela mesma, $e$ ver até que ponto, e com que consequiências, poderíamos colocar a tese T-P de Kant em termos da distinçào austiniana entre performativos e constativos.

Na idéia fundamental de Austin de que a linguagem, contrariamente ao que tradicionalmente se acreditara, pode ser usada nào apenas para dizer algo acerca do que é o caso, mas também para fazer dizendo - com que algo venha a ser o caso, podemos facilmente encontrar a questão kantiana (a) antes mencionada. A liberdade, pedra angular da teoria prática kantiana, coincidiria com a capacidade do ser humano de usar performativamente a linguagem, invertendo a relaçào habitual - constativa - respeito das coisas, e passando a constituir as coisas mesmas. A liberdade, apresentada por Kant como independência de determinaçòes sensíveis, independência a respeito da natureza e da experiência, seria agora compreendida como independência do mundo das coisas e das significaçōes objetivas, como independência de constrangimentos semânticos, como a capacidade de fugir da função puramente referencial da linguagem para passar a exercer funções instauradoras. Ou, para utilizar a frase de Austin, a liberdade 
consistiria na capacidade do ser humano de fazer coisas com palavras, em vez de a linguagem ser constituída apenas em decorrência do comportamento de coisas, num mero registro do que acontece, num fazer palavras com coisas. A liberdade, linguiisticamente concebida, seria, pois, dentro deste experimento, a própria capacidade de 'performar', de fazer com que coisas venham a ser o que são, fugindo da tarefa deterministica de simplesmente constatar aquilo que é ou não é. A noção de performativo forneceria algo assim com a gramática da liberdade, ou uma chave gramatical que nos encaminharia para ela: a liberdade dentro dos limites da simples performatividade. A segunda Crítica kantiana poderia considerar-se como um tratado metaético que mostra que não há teoria ética, mas somente liberdade, que não se podem denotar os 'objetos morais', mas apenas construí-los performativamente. ( $E$, neste sentido, o conceito de liberdade constitui, certamente, a pedra de escândalo para todos os semânticos.)

A possibilidade de lidar, no plano da açào, com objetos que não podem ser categorialmente construídos pela razão teórica como objetos de conhecimento passa a ser entendida, agora, como possibilidade de lidar com objetos que não podem ser referidos pela linguagem simplesmente através dos seus usos descritivos e constativos. A razão teórica kantiana estaria ligada, no modelo lingüístico austiniano, com estas funçōes puramente referenciais da linguagem, pelo qual seria pertinente estabelecer-se alguma vinculaçào profunda entre a construção categorial de objetos e a teoria da referência. Deus, imortalidade, liberdade, e, en geral, as coisasem-si, não são objetos que possam ser descritos mediante as funçōes referenciais da linguagem, mas devem ser performativamente constituídos em relaçāo com o agir. E aqui aparece a idéia (b) de Kant, acima mencionada: assim como para Kant os metafísicos dogmáticos cometeram uma grave confusão tópica ao construírem seus grandes sistemas racionais, segundo Austin os filósofos cometeram recorrentemente o que denomina "falácia descritivista", consistente em ignorar os usos não descritivos da linguagem, tratando-os como modalidades do descritivo: "...muitas perplexidades filosóficas tradicionais surgiram de um erro - o erro de aceitar como declarações factuais diretas proferimentos que ou são sem sentido ... ou então foram feitos com propósitos bem diferentes" (Quando dizer é fazer, 23). A liberdade não é concebida, como em Kant, como um 
novo tipo de determinação causal, mas como a simples possibilidade de usar a linguagem de maneira instauradora, criadora, realizadora. Assim, dever-se-ia igualmente estabelecer uma relação profunda entre a teoria da performatividade e o caráter ideal (não categorial) dos objetos prático-livres, como é apresentado na segunda Crítica e em muitos textos kantianos posteriores. A performatividade seria a possibilidade lingüística sobre a qual se funda o ato livre humano, a sua possibilidade de ir além do meramente constativo.

Tanto em Kant quanto em Austin, a noção fundamental que marca a passagem do teórico para o prático e do constativo para o performativo talvez seja a noção de ação, por sinal uma das noções centrais da filosofia contemporânea. Assim como Austin inaugura uma revolucionária teoria dos atos de linguagem (mais tarde sistematizada e articulada por J. Searle), pondo $o$ acento na capacidade da linguagem de fazer com que algo aconteca, pode-se ver na segunda Crítica kantiana uma tentativa de mostrar o caráter ativo e dinâmico da liberdade, a capacidade desta de realizar no mundo da natureza algo que não estava nem poderia estar previamente dado nele. " (...) a razão prática nào tem a ver com objetos para os conhecer, mas com a sua própria faculdade de tornar reais (wirklich $z u$ machen) aqueles (segundo o conhecimento dos mesmos objetos), isto é, com a vontade (...)" (Kant, CRPr, A 160). Mais adiante, na antinomia da razão prática, Kant se referirá ao "bem prático" como "um bem possivel pela ação" (was durch Handlung möglich ist) (Ibid, A 204).

A passagem da teoria para a prática em Kant parece apresentar uma estrutura semelhante à passagem dos interesses puramente semânticos, nos estudos da linguagem, para os interesses pragmáticos na história da Filosofia Analítica contemporânea. A liberdade se define pela característica de não deixar-se limitar pelos significados, acenando para um uso dinâmico e variável deles: mas, por isso mesmo, ela - a liberdade - não poderia ter 'significado' no sentido usual (e, nessa direção, a liberdade deve ser, literalmente, sem sentido); ela escapa ao significado, inaugura uma nova ordem de significaçào, em certa forma absurda e inassimilável para a semântica, para a pura descrição de significados no mundo. Em vez de dizermos que os objetos práticos devem ser transcendentalmente constituídos através de idéias puras práticas, dizemos austinianamente que os objetos práticos somente podem ser performativamen- 
te apresentados. A noção de um 'ideal da razão pura prática' se transforma numa possibilidade da linguagem.

Do primado do uso performativo da linguagem na sua conexão com o uso constativo

Esta primeira analogia entre Kant e Austin pode ser encontrada em autores como Paul Ricoeur, embora sem desenvolvimento:

A simples oposição entre constativo e performativo, tal como se encontra nas primeiras Conferências de Austin, proporciona uma dicotomia satisfatória para a reflexão: un kantiano encontra facilmente aqui a distinção do teórico e do prático que subjaz à dualidade das Críticas. (Ricoeur P, EI discurso de la acción, pág. 80)

A segunda idéia kantiana que quero submeter ao experimento austiniano aparece no parágrafo III do capítulo II da "Dialética da razão pura prática": trata-se da famosa tese kantiana do primado da razão prática sobre a teórica. Nesse conhecido trecho da segunda Crítica, Kant explica que cada 'faculdade da alma' tem um 'interesse', e que a razào tem a capacidade de determinar seu próprio interesse. "O interesse do seu uso especulativo consiste no conhecimento do objeto até os mais elevados princípios a priori, o do uso prático na determinação da vontade, em relação ao fim último e completo" (Kant, CRPr, A 217). "Se a razão prática nada mais houvesse de admitir e pensar como dado a não ser o que a razão especulativa lhe pudesse por si mesma apresentar segundo o seu discernimento, seria esta a ter o primado" (Ibid). Mas, segundo Kant, a razão prática possui "princípios originais a priori" indissoluvelmente ligados com

certas posiçōes teoréticas que, no entanto, se substraem a todo o possível discernimento da razão especulativa (...) [A] razào especulativa, que nada sabe de tudo o que a razão prática lhe propõe aceitar, deve admitir estas proposiçoes e procurar, embora para ela sejam transcendentes, uni-las com os seus conceitos como uma propriedade estranha para ela transferida... (Ibid)

A razão teórico-especulativa deve aceitar estas proposições como sendo de interesse prático, como "extensões do seu uso para um outro objetivo, isto é, prático..." (A 218).

Por isso, na ligação da razão pura especulativa com a razâo pura prática em vista de um conhecimento, o primado pertence à última, pressupondo, porém, que esta união não seja, claro está, contingente e arbitrária, mas fundada a priori na própria razão, por conseguinte, necessária. (lbid) 
Sem esta subordinação, segundo Kant, surgiria "um conflito da razão consigo mesma". "...todo o interesse é finalmente prático e mesmo o da razão especulativa só é condicionado e completo no uso prático" (Ibid). Em vários momentos da segunda Crítica, como já o tinha feito na primeira, Kant preocupa-se em frisar que, apesar de os objetos da esfera prática não poderem de maneira alguma ser construídos categorialmente na esfera teórica, esta não pode proibilos nem declará-los vazios ou absurdos, mas pelo contrário, vê-se como obrigada a reconhecê-los como possiveis, embora nâo sejam teoricamente constituíveis. $\mathrm{Na}$ necessidade imperiosa deste reconhecimento de algo estranho, e incompreensivel, reside, segundo Kant, o poderoso primado da prática sobre a teoria.

Este pequeno texto é, de alguma maneira, surpreendente para aquele que lê as três Críticas kantianas na sua seqüência histórica. Segundo foi elucidado pela Crítica da razào pura teórica, aquilo que podia ser conhecido permanecia dentro do âmbito categorial e esquemático, $e$ tudo aquilo que ultrapassasse esse nível devia ser considerado como sem sentido, ilegítimo e dogmático. No máximo, o leitor da segunda Crítica poderia ver ali uma tentativa de proporcionar algum 'lugar' para os objetos metafísicos expulsos pela Dialética Transcendental, mas nunca poderia imaginar que o interesse prático por eles, que tào comprometido parecia à luz da análise apresentada na primeira Crítica, apenas tentando 're-situar-se' comedidamente no mapa geral da razào pura, acabasse finalmente ganhando o primado da razão, e o privilégio de impedir que entre em conflito consigo mesma. Como um hóspede que primeiro ocupa modestamente um quarto de fundos e logo vai tomando conta do resto da casa, deixando seu próprio anfitriào na posiçào de hóspede, a razão prática comesa por aparecer como através das frestras dos usos teóricos da razão para, posteriormente, colocar-se num lugar de privilégio dentro da geografia da razão pura e de sua problemática fundamental.

Quero mostrar textualmente que uma estrutura semelhante de pensamento se apresenta também na teoria de Austin e, de uma maneira semelhante, no caráter intempestivo da sua apresentaçào textual. Assim como em Kant, a questào aparece em Austin como um tour de force ou como uma reviravolta inesperada, numa etapa já muito avançada da teoria. Com efeito, a questão aparece na conferência $V$ de How to do things with words, quando Austin começa a apresentar 
dúvidas a respeito da própria distinção entre 'constativo' e 'performativo', que ele tinha exibido nas conferências anteriores. A idéia fundamental, na qual se apoiava a distinçào, era a de que os performativos não podiam ser verdadeiros ou falsos, mas apenas 'felizes' ou 'infelizes', enquanto que os constativos se caracterizariam precisamente por serem verdadeiros ou falsos. Um proferimento que nāo se limitasse a constatar se algo é ou não o caso, mas que, no seu próprio exercício, fizesse com que algo que não era o caso viesse a ser o caso ou vice-versa, não poderia ser verdadeiro ou falso: apenas seria bem ou malsucedido na sua tentativa de realizar alguma coisa no mundo. De maneira semelhante, Kant tinha tentado demonstrar, na "Dialética Transcendental", que as afirmações da Teologia Racional, por exemplo, tampouco eram suscetíveis de serem verdadeiras ou falsas, por não tratarem com autênticos conceitos nem constituírem autênticos enunciados teoréticos acerca do mundo. Não obstante, Kant afirma, já na primeira Crítica mas sobretudo na segunda, que nem por isso aquelas afirmaçōes teológicas estão totalmente desvinculadas da razão e do mundo, como se se tratasse de puras fantasias arbitrárias. Através do interesse prático, essas afirmaçôes encontram de novo uma conexão com a razão, com a natureza e com a verdade, só que não mais num plano cognitivo.

...o bem moral é, segundo o seu objeto, algo de supra-sensível para o qual nâo pode, pois, encontrar-se algo de correspondente em nenhuma intuição sensivel e, portanto, a faculdade de julgar segundo leis da razão pura prática parece submetida a dificuldades particulares, que se devem ao fato de uma lei da liberdade dever ser aplicada a ações, enquanto eventos que sucedem no mundo sensível $e$, por conseguinte, fazem parte da natureza. (Kant, CRPr, A 121)

Assim, num primeiro passo, há um reconhecimento de que o uso prático da razão mantém uma necessária referência à natureza, embora tal referência deva ser resolvida de uma maneira diferente do que no caso do uso especulativo. Esta necessária referência da liberdade à natureza não é, em absoluto, incompatível com o afirmado, num segundo passo, acerca do primado do interesse prático sobre o teórico, através da argumentação acima exposta. A sujeição da liberdade à natureza é uma sujeição empírica, de possibilidade de aplicação, enquanto que a sujeição da natureza à liberdade é apresentada por Kant como uma necessidade práticotranscendental. 
É claro que a açào tem que ser possível sob condições naturais, caso o dever esteja orientado para elas; mas estas condições naturais não concernem à determinaçào do próprio arbítrio, mas sim unicamente ao efeito e à consequiencia do mesmo fenômeno. (CRP, 576)

De maneira semelhante, após Austin ter dito que os performativos nào podem ser verdadeiros nem falsos, nào obstante isso, ele se dá conta que os mesmos devem ainda manter conexōes importantes com o plano da verdade. Assim, por exemplo, na conferência $V$, ele tenta mostrar que para certos constativos serem verdadeiros ou falsos devem previamente ser felizes certos proferimentos - por exemplo "se o proferimento performativo 'Peço desculpas' é feliz, então a declaração de que estou pedindo desculpas é verdadeira" (57). Aqui pareceria mostrar-se uma espécie de dependência dos constativos para com os performativos. Mas, por outro lado, a inversa, segundo Austin, também se dá: para que certos proferimentos sejam felizes, é preciso que certas sentenças sejam verdadeiras - por exemplo, "Para que o proferimento performativo 'Peço desculpas' seja feliz, a declaração de que se dào certas condições...tem que ser verdadeira" (Ibid) -, o que mostraria uma dependência dos performativos para com os constativos. No momento de Austin começar a duvidar da nitidez da distinção performativo/constativo, ele passa a considerar a possibilidade de uma interação entre ambos, e não de qualquer tipo de 'primado' de um sobre o outro. A não-nitidez da distinção, segundo ele, faz com que os constativos pressuponham condiçòes de performatividade, e que os performativos pressuponham condiçōes de constatividade, numa dupla direção. Nào pareceria haver, pois, nesta visão das coisas, nenhum lugar para uma tese acerca do primado de alguma destas funçòes sobre a outra.

Mas, para formular corretamente um possivel primado do performativo sobre o constativo na filosofia da linguagem de Austin, não são esses os fatos que devem ser assinalados. A idéia fundamental deste primado nào é a de que uma constatação deva às vezes pressupor a felicidade de uma performação anterior, mas a idéia de que a própria constataçào é, sempre, e inevitavelmente, ela mesma, uma performação. Esta diferença entre 'pressupõe às vezes' e 'é sempre' é aqui fundamental. Um primado do performativo deverá hasearse na idéia de que constatar, registrar fatos, dizer como as coisas sào, etc, é sempre e inevitavelmente uma performação como qualquer 
outra. Na própria constatação, além da sua interna exigência de verdade ou falsidade, está também presente um elemento 'pragmático', de apresentaçào ou de proferimento, que deve ser satisfeito na sua exigência de êxito ou de 'felicidade', e sem a qual a própria constatação nào poderia ser realizada: uma asserção acerca de fatos deve ser apresentada de alguma maneira, num statement, exatamente como uma promessa ou uma desculpa, e só através de uma performance. A performatividade pode ser concebida, nessa linha de pensamento, como uma espécie de medium universal de apresentaçào de conteúdos. $D_{i-}$ zer o que é o caso é uma maneira entre outras de fazer com que algo venha a ser o caso. Una afirmação acerca do mundo deve ser também 'realizada'(performed), igual a qualquer outro performativo. Precisamente, no fato de os próprios constativos (a partir da conferência $V e$, sobretudo, na $\mathrm{XI}$ ) poderem ser considerados performativamente, basear-se-ia uma espécie de "primado do performativo sobre o constativo" na filosofia da linguagem de Austin.

A mencionada pretensa 'interação' entre performativo e constativo, que impediria colocar um primado do performativo, se movimenta num nivel de análise superfi- cial. Certamente, parece procedente afirmar que a realização de performativos exige certas condições fatuais, e a verdade ou falsidade de asserçòes exige certas condições de 'felicidade'. Mas esta 'interação' se movimenta no terreno de um mútuo 'pressupor' certas condições. Entretanto, existe uma assimetria entre o tipo de necessidade que $o$ performativo tem do constativo e a necessidade inversa: embora possa diser-se que certos performativos precisam de condiçöes de constatação para serem felizes, isso não permite afirmar que os performativos SEJAM constativos. Mas, pelo contrário, não acontece apenas que certos constativos precisem pressupor condições de felicidade para serem verdadeiros ou falsos, mas que qualquer constativo, agora $e$ sempre, precisa performar para constituir-se como uma constatação. Se não há performação, não existe, pura e simplesmente, asserção acerca do mundo. A asserção acerca do mundo não é apenas o conteúdo do afirmado, mas também o ato no qual esse conteúdo é posto. Portanto, a necessidade que a asserção acerca do mundo tem da performação é de caráter lógico. Pelo contrário, embora as performações se refiram a fatos, e precisem de que certos fatos sejam o caso, etc, essa necessidade é puramente empírica, do 
tipo: para entender geometria é preciso nào estar morrendo de fome, ou, para poder entender um diálogo de Platão, é preciso saber ler, etc. Esta assimetria é a mesma que encontrávamos nas relaçōes entre a liberdade e a natureza na filosofia de Kant. Certamente, a natureza é condição empírica de aplicaçào da liberdade, mas isso não lhe confere um primado sobre ela, nem mesmo estabelece uma 'interaçâo' com ela, no sentido de, às vezes, ela ter o primado, às vezes, não.

$E ́$ interessante salientar que enquanto Austin aponta, nas mencionadas conferências, para o caráter fuzzy da distinção performativo/

constativo, para Kant a distinção teórico/prático pareceu sempre perfeitamente legítima e necessária, à luz da filosofia transcendental, por mais complicado que fosse formular a natureza do prático e esclarecer suas relações com a teoria. Ora, se pelo contrário levarmos a sério o ceticismo de Austin a respeito da sua própria distinção, o paralelo com Kant poderia levar-nos a ser céticos a respeito da própria distinção teórico/prático na Filosofia Transcendental, como de fato o foram os idealistas pós-kantianos e muitos outros filósofos depois deles.
(Ver, mais adiante, a seção sobre idealismo lingüístico.)

Sabe-se que, precisamente, pelas dificuldades em definir com clareza a distinçào entre constativo e performativo, Austin tentará, a partir da conferência VIII de How to do things with words, um novo ponto de partida que dispense aquela distinção. Como a dimensào performativa e a constativa, segundo ele, se interpenetram, Austin prefere agora conceber um único ato de fala no qual se apresentem, ao mesmo tempo, diferentes dimensões, que são também atos, ou seja, uma espécie de ato inevitavelmente. 'misto' ou complexo: 1 . O ato locucionário, que consiste em proferir certas palavras de certa língua dotadas de um significado-referência convencional. 2. O ato ilocucionário, que consiste na força com a qual é feita a locução: pergunta, ordem, constatação, etc. 3 . O ato perlocucionário, que consiste no efeito que o proferimento busca obter por parte de um interlocutor.

A questão do primado do performativo sobre o constativo nāo mais poderia colocar-se neste novo esquema compreensivo, dado que o performativo e o constativo tornamse agora componentes de um mesmo ato complexo. Poder-se-ia até dizer que Austin adota esse novo esquema compreensivo para nào ter 
que decidir de quem é o primado, tentando entender a interaçào entre performativo e constativo dentro da complexidade de um único ato de fala. Mas poderia examinar se o primado não se reformularia, dentro deste ato de fala complexo, como primado da componente ilocucionário-perlocucionária sobre a locucionária. Igual a antes, e talvez com maior contundência, poderia reargumentar-se que, assim como não podem haver locuçōes sem ilocuções, a inversa também é o caso, de maneira que se daria sempre uma interaçào, e nào um primado em nenhuma de ambas direçōes. Nào se poderia defender um primado do ilocucionário sobre o locucionário, na medida em que nenhuma locução pode prescindir de una certa força de proferimento, mas tampouco existe ilocução sem locuçào. Aqui a reciprocidade parece clara.

Mas a contra-argumentação kantiana poderia aqui reapresentarse: certamente, a ilocução precisa exercer-se numa locuçào, precisa de um conteúdo locucionário, mas é esta uma precisão de tipo empírico, e nào lógico ou transcendental, o mesmo tipo de precisão que a liberdade tem da natureza para exercerse como liberdade (e que levará Fichte, anos mais tarde, a declarar que este mundo é o mundo perfeito para ser moral, porque a totalidade da natureza se opōe permanentemente ao exercício do ato livre). Pelo contrário, sem componente ilocucionária, a locução não pode ser nem mesmo apresentada, porque a sua própria apresentação exige já uma força (e talvez um efeito) - só pode ser apresentada através de uma ilocução. Assim, tanto a componente locucionária quanto a ilocucionária são indispensáveis para a realização do ato de fala total, mas - kantianamente vistas - não possuem o mesmo tipo de indispensabilidade. $O$ conteúdo locucionário não faria parte, nesta interpretação, da estrutura lógica do ato, mas constituiria apenas o lugar vago de um conteúdo possível, igual a quando, em Lógica, nào dizemos que os conteúdos tenham um primado sobre as formas lógicas pelo fato de que, sem conteúdos, não teríamos sobre o que aplicar as formas lógicas. (É na conferência XI, após ter abandonado a distinção performativo/constativo, que Austin, paradoxalmente, expõe com maior convicção o primado do performativo, no sentido dos constativos serem também performações.)

\section{Kant e a linguagem}

Como o assinala Dascal no mencionado artigo, Kant, seguindo nisto uma forte tradição, nunca conseguiu ver na linguagem outra 
coisa que um veículo inessencial de significaçôes geradas num outro lugar. A linguagem não carregaria nenhuma função constitutivo-transcendental, mas apenas seria um acompanhamento externo de processos e de sínteses nos quais a linguagem não participaria de maneira 'interna'. É o caráter arbitrário do signo lingüístico aquilo que fez com que os filósofos de todos os tempos o considerassem como uma estrutura secundária, mais do interesse de filólogos e lexicógrafos do que de filósofos stricto sensu. Mas esta situaçào modesta da linguagem é pensada em todo momento, no caso de Kant, dentro do âmbito da questão teórica da razão. No momento de pensar, dentro da filosofia transcendental teórico-especulativa, em estruturas que sejam capazes de vincular não arbitrariamente elementos categoriais com elementos sensíveis, como os esquemas transcendentais apresentados na "Analítica dos princípios", Kant nunca concebe tais estruturas como sendo lingüísticas, como sendo signos. Se os esquemas transcendentais fossem signos, seriam apenas transcritivos de algo que acontece na conciência transcendental e que pode ser elucidado através da Analítica. Nào se precisaria ali, segundo Kant, de um estudo da linguagem. Aí onde, no plano da problemática teórica da razão, a arbitrariedade é quebrada, a linguagem está ausente, ou presente de maneira inessencial. Mas parece que o lugar da filosofia kantiana, no qual a quebra da arbitrariedade da relaçao entre signos e coisas poderia ser naturale fortemente vinculada com certas funções da linguagem, é o âmbito da prática e nâo da teoria, e o presente trabalho tentou acenar precisamente para essa possibilidade. Kant parece nunca ter pensado na possibilidade de que a linguagem pudesse desempenhar um papel mais importante, de caráter constitutivo-transcendental, na passagem da teoria para a prática, e no próprio âmbito prático já constituído.

Para falarmos em termos austinianos, no plano meramente constativo a linguagem aparece apenas como especular, representativa e externa. Mas no plano da liberdade, no plano no qual transformaçōes do mundo são realizadas através de ações, não poderia, por exemplo, o caráter performativo das emissões lingüísticas ser considerado como uma componente constitutiva dessa liberdade, dessa originária capacidade do ser humano de transformar o mundo em vez de simplesmente constatá-lo? A não-arbitrariedade da liberdade transcendental, como capacidade de opor-se a determina- 
ções naturais, poderia ser concebida como constitutivamente ligada com a capacidade performativa da linguagem. Dito de maneira mais provocante: nào poderia a dimensâo performativa da linguagem ser considerada francamente transcendental, indicadora de uma capacidade fundamental da razão humana - transformar o mundo através da fala, fazer coisas com palavras mais além da sua capacidade constativa, que sempre pode interpretarse apenas como concomitância, nunca como constituiçâo? A performatividade seria assim visualizada não como algo apenas ligado à análise de enunciados, mas com uma capacidade fundamental, ou com uma abertura originária ao mundo através do exercício da linguagem. Precisamente, o caráter puramente arbitrário da linguagem se manifestaria toda vez que a linguagem tentasse apenas registrar o mundo. A performatividade sugeriria uma vinculaçào mais interna entre signos lingứísticos e coisas, na medida em que coisas estariam sendo realizadas através desses signos lingüísticos e não de outros. Na possibilidade fundamental de poder fazer coisas com palavras, a arbitrariedade do signo ficaria sensivelmente diminuída. (Há explicações históricas de por que Kant nunca pensou a questão da linguagem dentro do âmbito da problemática prática, através das funções da linguagem ligadas com a liberdade. Na época de Kant, os estudos linguíísticos estavam voltados mais para questões histórico-comparativas, ligadas com a evolução das línguas e a sua diversidade, do que para qualquer tipo de estudo das suas funções constitutivas ligadas com a formação de conceitos.)

Porém, Austin - inaugurador da problemática dos performativos na teoria da linguagem - nos oferece apenas uma versão empíricoconvencionalista da performatividade, sem nenhum elemento transcendental, apesar das frequientes e elogiosas mençôes de Kant. A vinculaçào das palavras com as coisas nas performaçôes é possibilitada, segundo Austin, através de regras convencionadas e até institucionalizadas, e não através de uma vinculação interna mais ligada com o transcendental kantiano, ou com qualquer outra conexão de natureza lógica. Esta pode ser, talvez, a limitação mais radical da tentativa de uma leitura austiniana de Kant. Parece que o paralelismo funciona bem quando se trata de explicar a passagem do teórico para o prático, mas não quando se trata de explicar a estrutura mesma do prático. Qualquer relação do prático kantiano com contextos de usos socializados, 
'circunstâncias adequadas', convençōes socializadas, e assim por diante, parece claramente ilegítima, incompativel com a concepção kantiana do prático. A liberdade é a capacidade - individualmente constatada - de performar. Mas a performaçâo não é, para Kant, bem-sucedida com base em critérios convencionais externos, que seriam claramente 'heterônomos' no caso das açòes morais, mas em virtude de uma determinação a priori prática (a lei moral) da performação livre, ou seja, de uma determinação racional. Uma teoria forte de razão falta totalmente em Austin e seria claramente incongruente com a sua maneira de conceber a filosofia e a análise linguística. Assim, neste ponto, trata-se, se queremos conservar a performatividade como característica da liberdade, de construir uma teoria transcendental da performatividade, alem da sua concepçào puramente empírico-convencional em Austin. (Algo semelhante ao que propòe Apel quando aborda a teoria de Wittgenstein, das Investigaçôes Filosóficas, ou a teoria de Peirce.) Esta teoria seria parte de uma teoria transcendental - ou hermenêutico-transcendental - da linguagem, uma teoria claramente nào analítica. Isto poderia acenar também para as limitações de uma tentativa analítica de reconstrução de elementos transcendentais, assim como Ricoeur aponta, por exemplo, para as limitações das tentativas analítico-lingüísticas de reconstrução de aparatos conceituais gerados dentro da Fenomenologia.

Neste sentido, e voltando às alternativas (a)-(c) de uma leitura lingüística das teses kantianas da passagem do teórico ao prático e do primado do prático sobre o teórico, eu manteria o experimento austiniano no nível intermediário (b): nào me comprometeria com a tese analítica forte de que as teses kantianas são, na verdade, teses acerca da linguagem. Preferiria, pluralisticamente, manter o ponto de vista transcendental como alternativo ao analítico, num 'conflito de interpretações', em vez de tentar a qualquer custo - via Austin, neste caso - dar uma versão totalmente 'pós-metafísica' da teoria kantiana do prático. Porém, não sustentaria algo tào fraco quanto que se trata apenas de uma transcrição inessencial. Tratase, a meu ver, de uma tese lingüística paralela que esclarece a teoria kantiana sem pretender substituí-la, sugerindo que a questào linguagem poderia introduzir-se na filosofia kantiana na sua dimensão prática, sem ferir os princípios da sua filosofia, na medida em que o poder da liberdade se refletiria regularmente muma certa capacidade da linguagem. 


\section{Idealismo lingüístico}

Nos denominados 'idealismos' pós-kantianos, nesta linha de leitura, realizar-se-ia algo assim como a total 'performativização' da linguagem, a total primazia da liberdade sobre a ciência como conhecimento do mundo, na medida em que toda e qualquer ação humana seria realizada em virtude de uma liberdade originária, através de uma performaçào radical do mundo. A ciência se transforma, neste contexto romântico, numa narrativa ao lado das outras, e nem mesmo das mais interesantes.

En Fichte, o ser é substituído pela pura ação (Tathandlung) do eu originariamente livre.

A inteligência é, para o idealismo, um agir, e absolutamente mais nada; nem mesno deve chamar-se um ser ativo, já 'que por tal expressào se denotaria algo subsistente dotado de atividade (...) [A] inteligência sente não uma espécie de impressão procedente do exterior, mas sente naquele agir os limites da sua própria essência. (Fichte, Primeira introduçào à doutrina da ciencia, par. 7)

Fichte insiste, em muitos lugares, que a doutrina da ciência "...coincide plenamente com a filosofia kantiana e nào é outra coisa do que a filosofia kantiana corretamente entendida", precisamente baseando-se em que a sua teoria não se apóia na captação de um ser, mas de um puro agir. "A intuição intelectual de que fala a Doutrina da ciência [diz Fichte] nāo se dirige de modo algum para um ser, mas para um agir, e em Kant ela não é mencionada..." (Segunda introdução, par. 6). As críticas kantianas contra a intuição intelectual não poderiam atingir, pois, esta captação de um puro agir livre. A própria objetividade é um produto desta atividade originária:

Mediante o pensar, o atuar pensando nele se faz para o filósofo objetivo, quer dizer, se oferece diante dele como algo que, enquanto pensado, refreia a liberdade (a indeterminação) do seu pensar. Esta é a verdadeira e originária significação da objetividade. Tào certamente como que penso, penso algo determinado, pois de outra maneira não pensaria em nada. (Ibid. par. 7)

Este processo se dá, em Fichte, como a experiência fundamental de um eu. "A afirmação básica do filósofo como tal é a seguinte: na medida em que o eu é somente para si mesmo, surge para ele, ao mesmo tempo e necessariamente, um ser fora dele" (Primeira Introdução, 3). O eu se constitui neste agir reversivo, ele não existe anteriormente a ele. "O eu reverte em si mesmo, afirma-se. Mas não existe já ele antes deste reverter e independentemente do mesmo?...Não, em modo 
algum...por meio de um agir sobre um agir...vem o eu a ser originariamente para si mesmo" (Id, 4). $O$ idealismo fichtiano parece, assim, 0 próprio âmbito do fazer coisas com palavras. Lembremos que um dos critérios que Austin tenta fornecer para identificar os performativos é a sua forma gramatical de "primeira pessoa do singular do presente do indicativo da voz ativa" (Austin, Quando dizer é fazer, p. 24). Como assinala Paul Ricoeur: "...no constativo, o sentido da proposição não muda com as pessoas (eu, tu, ele come, corre, etc); no performativo, somente a primeira pessoa do singular dá ao verbo sua força de performativo. A simetria das pessoas é pois característica do constativo" (Ricoeur Paul, El discurso de la acción, p. 80). Mas nesta tentativa de caracterizaçāo gramatical do performativo, o eu não é o fundamental, mas o tempo verbal: "Eu te batizo" é performativo, enquanto 'Eu te batizei' é constativo. O eu que interessa a Fichte é apenas o eu que acompanha o verbo em presente indicativo ativo, aquele que em cada caso diz eu e ao dizê-lo faz alguma coisa ser.

De todas as maneiras, como todos os filósofos da tradiçào anterior ao linguistic turn contemporâneo, Fichte se mostra cético perante algumas críticas contra a sua noção de eu, que ele acredita decorrentes de considerações puramente linguiísticas. Por exemplo, a seguinte:

'Eu' denota a minha pessoa concreta... Ora, se faço abstração, como pede a Doutrina da ciência, desta personalidade individual, não fica nenhuma outra coisa que possa caracterizar-se pelo eut, ao que resta poderia chamarse igualmente de isso. (Segunda introdução, 9).

E Fichte, iradamente, responde: "...acaso essa objeção se apóia no uso corrente da linguagem, querendo-se dizer que na linguagem não se designa, mediante a expressão eu, outra coisa do que a individualidade?" (Ibid). Se isto fosse verdade, "...se seguiria entào do fato de até hoje nào ter sido notada ou designada na linguagem uma distinção que podemos comprovar na síntese originária, que tal distinção não deva ser notada ou designada nunca?" (Ibid). A continuaçào, Fichte tenta mostrar - mas de uma maneira puramente ilustrativa que tanto na linguagem técnicofilosófica quanto na linguagem vulgar - se é que a reflexào vai ter de se movimentar em terreno 'lingüístico"! - pode ser encontrada a noção de eu que interessa à doutrina da ciência.

A tese da liberdade como performatividade tentaria captar aquela tese idealista forte (em termos da 
capacidade da linguagem) de radicalizar a construção do real através da linguagem. Mas esta maximalização do performativo acaba com a própria distinção constati/performativo. A performativização do real rouba todo o sentido da própria antiga distinção entre performativo e alguma outra coisa. Do plano no qual se faziam coisas com palavras, chega-se a um âmbito onde a mesma coisa é pura palavra.

Richard Rorty apresenta, num capítulo de Consequences of pragmatism, os 'textualistas' da Escola de Yale (Bloom, Hartmann, Miller, Paul De Man) e os post-estruturalistas franceses como Derrida e Foucault, como contrapartidas atuais do idealismo do século XIX: enquanto estes sustentavam - segundo Rorty - que não havia outra coisa senão idéias, os textualistas sustentariam que não existe outra coisa além de textos, e que uns textos remetem a outros textos, e não a uma 'realidade externa'. A performatividade radicalizada poderia entender-se no nível deste textualismo, e Austin forneceria mais um vocabulário para formular aquilo que Rorty poderia chamar uma versão postfilosófica do idealismo, entendido agora sobriamente como a crença na incontornável mediaçăo da linguagem na constituição de conceitos. A despeito do escasso valor que atribuíram à questão da linguagem, os próprios 'idealistas' do século XIX, se convenientemente 'transcritos' nas linhas aqui desenvolvidas, poderiam representar expressivamente a ultrapassagem da teoria tradicional da linguagem - desde o Crátilo platônico até Kant - em benefício de uma teoria constitucional da linguagem.

\section{Referências Bibliográficas}

APEL, Karl Otto. De Kant a Peirce: la transformación semiótica de la lógica trascendental. In: La transformación de la Filosofía. Madrid: Taurus, 1985. 2 vs.

AUSTIN, J. L. How to do things with words. Oxford: s.n., 1980. . Quando dizer é fazer. Palavras e ações. Porto Alegre: Ed. Artes Médicas, 1990.

DASCAL, Marcelo. Kant: lenguaje y conocimiento empírico. (Inédito). FICHTE, Johann G. Introducciones a la doctrina de la ciencia. Madrid: Tecnos, 1987. 
GLOUBERMAN, Mark. Transcendental idealism and the end of phi losophy. Metaphilosophy, v.24, n. 1/2, jan/apr. 1993.

GOODMAN, Nelson. Ways of worldmaking. 4. ed. Indianapolis: Hackett Publishing Company, 1985.

HABERMAS, Jurgen. Teoría de la acción comunicativa: complementos y estudios previos. Madrid: Cátedra, 1989. . Pensamiento postmetafísico. Madrid: Taurus, 1990.

KANT Immanuel. Crítica da razão pura. São Paulo: Abril Cultural, 1980. (Os Pensadores).

- Kritik der praktischen Vernunft. In: Kant, I. Werke. Band Darmstadt: Wissenschaftliche Buchgesellschaft, 1983. . Crítica da razão prática. Lisboa: Edições 70, 1989.

RICOEUR, Paul. El discurso de la acción. Madrid: Cátedra, 1988.

RORTY, Richard. Nineteenth-Century Idealism and Twentieth-Century Textualism. In: Consequences of Pragmatism. Minneapolis: The Harvester Press, 1982.

SEARLE, John. Speech acts: an essay in the philosophy of language. Cambridge: Cambridge University Press, 1969. . Expression and meaning; studies in the theory of speech acts. Cambridge: Cambridge University Press, s.d. 